DOI: $10.12737 /$ jflcl.2020.043

\title{
Theoretical and Practical Problems of Obligatory Professional Liability Insurance: A Comparative Analysis on the Basis of the Russian and Estonian Laws
}

\author{
M. V. Kratenko a, O.-J. Luik \\ aSiberian Federal University, Krasnoyarsk 660041, Russian Federation \\ bLaw Firm LEXTAL, Tallinn, Estonia \\ E-mail: maxkrat@yandex.ru; olavi@lextal.ee
}

The number of fields, in which different countries are enforcing the obligatory liability insurance, is growing. It is an increasing trend. However, in private law, there is the principle of freedom of contract, which raises the question, is it being breached? What, if any, requirements can the state enforce on private relationships? The authors examine the principles of liability insurance and topical problems in the context of obligatory professional liability insurance. The research is based on two neighbouring countries: the Russian Federation and the Republic of Estonia (while the Estonian legal environment is in many ways influenced by the legislation and legal practice of the European Union). The proliferation of obligatory liability insurance is decreasing the number of tort claims (since many of the damages are compensated by the insurer if the insurance policy is in force). The authors consider that the liability insurance fulfils a dual purpose: ensures a compensation for the injured party and at the same time prevents the potential insolvency of the tortfeasor. So, the enforcement of obligatory professional obligatory liability insurance is justified in many professional practices: legal consulting, medical care services, appraisal activity.

Despite the differences in legislation on certain types of professional activity, similar legal issues have been discussed by lawyers and scholars: how to determine the occurrence of an insured event (trigger); should insurance be extended to cases of intentional errors and omissions; whether the victim has the right to choose the subject of compensation (between the insurer and tortfeasor)? The comparative legal method of research allows the authors to offer optimal solutions to the above problems.

Keywords: actio directa, obligatory insurance, professional liability insurance, professional errors and omissions, insured event, act committed trigger, occurrence trigger, deliberate damage.

For citation: Kratenko M. V., Luik O.-J. Theoretical and Practical Problems of Obligatory Professional Liability Insurance: A Comparative Analysis on the Basis of the Russian and Estonian Laws. Zhurnal zarubezhnogo zakonodatel'stva i sravnitel'nogo pravovedeniya $=$ Journal of Foreign Legislation and Comparative Law, 2020, no. 5, pp. 81-94. DOI: 10.12737/jflcl.2020.043

\section{Introduction}

Legal literature points out that professional liability insurance is widespread in the civilized world. In the system of Russian insurance law, professional liability insurance is one of the youngest and most insufficiently developed spheres. The experts note the low volume of professional liability insurance in the total volume of insurance services provided. At the same time, this area of insurance activity, taking into account international experience, is one of the most promising and in the near future, the most required in Russian society ${ }^{1}$. According to the authors, a similar conclusion can be drawn on professional liability insurance in Estonia. Due to their historic neighborhood, the authors examine how professional liability insurance has developed in these two countries and what the significant practical problems are.

In the present study, the authors analyze obligatory professional liability insurance in the comparative analysis on the example of the Estonian and Russian laws, in the following issues: (a) the basis and principles of introducing obligatory professional liability insurance; (b) what is to be considered as an insured event in obligatory professional

${ }^{1}$ Sitdikova L. B., Shilovskaya A. L., Volkova M. A., Lenkovskaya R. R., Stepanova N. A. Legal Regulation of the Professional Liability Insurance of a Consultant in Russia and Abroad, Journal of Advanced Research in Law and Economics, 2016, vol. VII, iss. 2 (16), p. 364. liability insurance; (c) the effect of intent on the insurer's performance obligation in obligatory professional liability insurance; and (d) what are the legal consequences of an obligatory professional liability insurance contract not being concluded or not having been concluded in accordance with the law?

1. The obligatory professional liability insurance: origin and scope

1.1. Grounds for the introduction of obligatory professional liability insurance

Legal literature ${ }^{2}$ holds that liability insurance has evolved as a voluntary transaction designed to avert the ruinous consequences of civil liability vis-a-vis third parties may have for the policyholder. Over time, scientific and technological progress has considerably increased the risk inherent in certain activities and has given rise to new, formerly unknown and particularly risky types of action. Those engaging in such activities have often no sufficient means to meet the consequences of those risks or have tried to reduce their risk exposure, for example, by means of corporate veils. The consequences of these developments have been a shift of risks to third parties uninvolved, but affected by, the policyholder's activities. At the same time, this shift of risks could not be avoided by strengthening the liability

${ }^{2}$ Basedow J., Birds J., Clarke M. Principles of European Insurance Contract Law (PEICL). $2^{\text {nd }}$ ed. Köln, 2016. Pp. 309-310. 
regime, introducing strict liability of persons engaging in hazardous activities.

Liability insurance is by nature a type of non-life insurance. The necessity of liability insurance results from the fact that it helps to bear the economic risk arising from the occurrence of civil liability. Liability insurance, for example, helps to mitigate the risk that, for a number of professions (notaries, bailiffs, etc.), a third party will make large claims against the person who caused the damage, which the policyholder himself or herself would not be able to recover. In the case of liability insurance, the insurance risk shall be the emergence of the civil liability of the policyholder. The insured event, in turn, may be defined as a violation of a third party's legal interest, an emergence of damages for the injured party or a claim for damages against the policyholder.

Liability insurance has a dualistic protection purpose: the insurance contract provides the injured party with protection against a potential economic disaster that could result from a negative judgment while guaranteeing the injured third party the right to compensation even if the injuring party proves to have insufficient assets to fulfill his or her obligations $^{3}$. T. Honoré has noted ${ }^{4}$ that insurance is a standard mechanism for dispersing damages while at the same time helping to protect the claimant's right to compensation. At the same time, the principle of distributive justice - ius distributiva — which seeks to distribute liabilities roughly in the same proportion to the benefits, also seek to disperse damages. Persons who benefit from certain activities, such as the use of a motor vehicle, bear a proportionate share of the damages caused by their activities, e.g., through obligatory liability insurance. Mr. Honoré also stated that such risk dispersion is certainly not an infallible instrument of fairness, as insurance premiums may be disproportionately high. However, it does help to ensure that, in most cases, tortious damage is not significantly disproportionate to the fault of the person who caused the damage. Thus, while the dispersion of damage through liability insurance is distributive in nature, the reason it is needed as an instrument of the law of tort, at least in part, is to meet the requirements of retributive justice - fair compensation. This will help to mitigate damages which, irrespective of the defendant's fault or absence thereof, are extremely serious. This does not mean that dispersing damage is an objective of the tort system, but that some types of insurance are important to the effective functioning of corrective justice.

In insurance theory and insurance practice, liability insurance is divided into professional liability insurance $(P L I)$, also called professional indemnity insurance

\footnotetext{
${ }^{3}$ Honoré T. The Morality of Tort Law: Questions and Answers. Philosophical Foundations of Tort Law. Ed. by D. G. Owen. Oxford, 1995.

${ }^{4}$ Ibid.
}

$(P I I)$ or errors \& omissions $(E \& O)^{5}$ and general liability insurance. Examples of professional liability insurance are professional insurance of a lawyer, insurance broker, auditing firm, bailiff, notary, bankruptcy trustee, patent attorney, doctors, engineers, architects, etc. Examples of general liability insurance are company liability insurance, building owner liability insurance, hydrotechnical facility owner liability insurance, employer liability insurance, product liability insurance, event organizer liability insurance, etc.

Liability insurance can be further divided into voluntary and obligatory liability insurance ${ }^{6}$. The objectives distinguish between these two forms: the purpose of voluntary liability insurance is to release the person who caused the damage from the obligation to pay compensation, and the purpose of obligatory liability insurance is to compensate for the damage of the injured party. The difference also resides in the fact that in the case of a voluntary liability insurance, there is no obligation to conclude a contract, whereas when it comes to obligatory liability insurance, it is a necessity. Furthermore, the voluntary liability insurance generally does not allow the injured party to file a direct claim against the insurer, while the obligatory liability insurance does. In addition, in terms of the voluntary liability insurance, the extent of the insurance cover is largely a matter of agreement, whereas, there are often some kind of criteria given by normative acts regarding the insurance cover of obligatory liability insurance.

One of the most important principles of private law is the principle of freedom of contract, which means that all persons are free to decide whether and with whom to conclude a contract (freedom of contract) and with what content (freedom of content) ${ }^{7}$. In light of the foregoing, the question arises whether the introduction of obligatory liability insurance does not infringe on the principle of freedom of contract. Obligatory liability insurance is, in essence, a restriction on contractual freedom - the so-called compulsion of a contract ${ }^{8}$. In order to avoid the risk of devastating consequences for both the injured party and the person causing the damage, the legislature imposes an obligation (duty) to take out liability insurance for certain different activities and

\footnotetext{
${ }^{5}$ The purpose of PLI is to protect individuals and companies that provide professional advice (e.g., legal malpractice) and services (e.g., medical malpractice, etc.) from customer claims for negligence damage. The term errors and omissions (E\&O) is more commonly used in the US and refers to the liability insurance of consultants, brokers and agents.

"In insurance theory the term "compulsory" liability insurance is also common. It can be used as well.

${ }^{7}$ Guaranteed in the Republic of Estonia by $\S 19,31$ and 32 of the Constitution.

${ }^{8}$ Schlechtriem P. Law of Obligations. General part 18. Ver. 2. Tallinn, 1999.
} 
professions ${ }^{9}$. As a result, obligatory liability insurance, as a restriction of freedom of contract, serves the purpose of ensuring compensation for the injured party while preserving the solvency of the person who caused the damage. State intervention in the risk management of natural and legal persons through the introduction of obligatory classes of insurance stems from the desire to provide economic insurance, to protect the interests of victims and to protect the person causing the damage from possible bankruptcy. Without state intervention, many risk-takers would not insure themselves. Thus, for the sake of society as a whole, it is necessary for the state to introduce obligatory insurance to manage certain risks $^{10}$.

In legal doctrine, pleas in favor of obligatory liability insurance are often heard. A duty to insure is seen as a guarantee to the victim. If insurance is available, the victim will always receive compensation. The favoring of obligatory liability insurance can be explained by the concern for victim protection. To many lawyers, the main purpose of accident law, is the compensation of the innocent victim. Obligatory liability insurance could remedy the potential insolvency of the policyholder ${ }^{11}$.

According to the authors of the article, states consider it necessary to intervene in people's behavior by introducing obligatory insurance systems:

people often do not have sufficient insurance interest in voluntary liability insurance, as they expect the attitude of being diligent to avoid damage;

insurance risk is not sufficiently dispersed in the case of voluntary insurance, as less wealthy natural and legal persons would often circumvent insurance;

it is of the state's interest to leave expenses, which would otherwise be paid from the state budget, for the private (insurance) sector to bear.

Thus, the authors consider that limiting the freedom of contract through the obligation of contract, is justified in certain cases, as it ensures a more stable social organization.

${ }^{9}$ Langheid T., Römer W. Versicherungsvertragsgesetz. 2 Aufl., Verlag C. H. Beck, München, 2003. S. 955, Rz 5.

${ }^{10}$ The authors focus their article exclusively on statutory professional liability insurance. The legal literature explains that for some professionals, the "burden" of insurance has been made compulsory, either by the legislature or by the profession itself. Thus, in the UK, accountancy firms wishing to undertake investment business must, in order to obtain "professional body status" from the Securities and Investment Board, have obligatory professional liability insurance. See: Whelan C. J., McBarnet D. The "Crisis" in Professional Liability Insurance, 14 (53). The Geneva Papers on Risk and Insurance, 302 (1989). Thus, in practice, an obligation to take insurance is "imposed" outside the law through professional organizations.

${ }^{11}$ Faure M., Van den Bergh R. Compulsory Insurance for Professional Liability, 14 (53). The Geneva Papers on Risk and Insurance, 312 (1989).

\subsection{The scope of obligatory professional liability insurance in Estonia}

The Republic of Estonia has dozens of laws ${ }^{12}$ that provide for obligatory liability insurance. As regards to professional liability insurance, therefore the following obligatory liability insurance have the greatest importance in the Republic of Estonia: Bankruptcy Trustees professional liability insurance, professional liability insurance of notaries, lawyers professional liability insurance, professional liability insurance of bailiffs, insurance brokers professional liability insurance, professional liability insurance of patent attorneys, auditors' professional liability insurance, etc..$^{13}$

It is the insurance brokers liability insurance that there is the most in judicial practice in Estonia.

For example, by the judgment of the Harju County Court in the case No. 2-17-14114, OÜ Tiib Kindlustusmaakler is ordered to pay about 55,000 euros because the insurance broker had forgotten to sign an insurance contract for the policyholder's mini loader for a new insurance period. According to the

${ }^{12}$ For example, compulsory liability insurance in Estonia is regulated by the following legislation. General liability insurance: $\S 14$ of the Railways Act (SG I 2003, 79, 530 ), § 3 of the Liquid Fuel Act (RT I 2003, 21, 127), $§ 25$ of the Chemicals Act (SG I, 10 November 2015, 2), § 91 (1) 5, 100 of the Waste Act (SG I 2004, 9 , 52). Professional liability insurance (Professional indemnity): $§ 64$ of the Bankruptcy Act (SG I 2003, 17, 95 ), § 15 of the Notaries Act (SG I 2000, 104, 684), Section 10 of the Bailiffs Act (SG I 2009, 68, 463), Section 48 of the Bar Association Act (SG I 2001, 36, 201), $\S 63$ of the Auditing Practices Act (SG I 2010, 9, 5), § 11 of the Patent Attorneys Act (SG I 2001, 27, 151), and $§ 179$ of the Insurance Activities Act (SG I, 7 July 2015, 1). In addition, several laws provide for the need/possibility/prerequisite for liability insurance: $\S 31$ of the Unemployment Insurance Act (SG I 2001, 59, 359), § 22 of the Estonian Health Insurance Fund Act (SG I 2000, 57, 374), $\S 6$ (2) 9 of the Articles of Association of the Guarantee Fund (SG I 2002, 54, 342), § 336 (1) (SG I, 31 December 2016, 3), § 28 (1) (10) of the Product Conformity Act (SG I 2010, 31, 157), § $19^{2}$ of the Maritime Safety Act (SG I 2002, 1, 1) - with reference to the Product Conformity Act, Electronic Communications Act $§ 120^{1}$ (SG I 2004, 87, 593) — with reference to the Product Conformity Act, with Measurement Act $§ 13$ (SG I, 25 May 2018, 1) — with reference to the Product Conformity Act, Precious Metal Products Act $\S 41$ (SG I 2003, 15, 85), $\S 14$ of the Medical Device Act (RT I 2004, 75, 520) - with reference to the Product Conformity Act.

${ }^{13}$ Among other things, the Patient Insurance Act, aimed at the introduction of compulsory professional liability insurance of healthcare professionals (doctors, nurses, etc.) to compensate the patient for the damage suffered during a health care which could reasonably have been avoided, is currently under development in the Republic of Estonia. In order to compensate for health damage, it is not necessary to establish the fault of the health care professional, but preventability is important. The law is expected to be adopted in 2020. Available at: file://C:/Users/user/Downloads/ PKS_EN_\%2022052019\%20(1).pdf. 
agreement between the parties, the insurance broker had the obligation to renew the insurance contracts.

In the case No. 2-14-50446, the Tallinn Circuit Court held that an insurance broker is responsible for advising a client to enter into an insurance contract with underinsurance, thereby violating the obligations arising from the brokerage contract in mediation of the insurance contract. Namely, the insurance broker has a duty of care and due diligence in identifying the insurance interest and in presenting the insurance terms and conditions, in the interest of the client.

In the case No. 2-14-11491, the Tallinn Circuit Court found that an insurance broker is responsible if the client wants insurance coverage against all risks, but the insurance broker only offers construction comprehensive risk insurance that did not specifically cover the event, whereas liability insurance would have covered it, i.e. the insurance broker did not recommend all possible insurance policies although this was the policyholder's wish.

Thus, in Estonia, insurance services aimed at legal professionals (notary, lawyer, bailiff, etc.) play a major role in obligatory professional liability insurance classes in Estonia. The reason for this is, according to the authors, that the representatives of this profession have a higher level of trust in society and their work may result in greater damage than usual, which may be irreversible (for example, losing a home in a lawsuit, etc.) for the injured person (in the case of a legal professional's failure to provide legal services). Moreover, the damages caused by these people are more socially sensitive and generally vastly covered in the media, which can thereby put pressure on authorities/agencies/departments/offices.

\subsection{The scope of obligatory professional liability} insurance in Russia

In accordance with the Russian law, representatives of only three professions are required to have an obligatory liability insurance policy: notaries, appraisers and bankruptcy trustees ${ }^{14}$. Until December 2008, audit organizations had also a duty to insure the risk of professional liability, when conducting a mandatory audit ${ }^{15}$. Some auditors' associations even after 2008 retained such requirement as a condition of membership. This practice is considered acceptable in so far as it ultimately protects the property interests of audit clients.

LLC "Missaudit" (Company) filed the claim against the self-regulatory auditor's organization "Audit chamber of Russia" (SRO) to rescind the provisions of par. 13 (5) of

${ }^{14}$ See Art. 18 of the Notary Act of 11 February 1993 No. 4462-I; Art. 24.7 of the Evaluation Activity Act of 29 July 1998 No. 135-FZ; Art. 24.1 of the Bankruptcy Act of 26 October 2002 No. 127-FZ. The category "professional liability insurance" is used in the narrow meaning, which is different from general liability insurance. Therefore, contrary to popular opinion in the literature, the authors do not consider tour operator liability insurance as a type of professional liability insurance.

${ }^{15}$ See Art. 13 of the Audit Activity Act of 7 August 2001 No. 119-FZ, invalid since 1 January 2009. the Charter of SRO, which impose on SRO's members the obligation to insure their professional liability. According to the plaintiff, this clause does not correspond to the legislation on audit activity, since the Audit Activity Act (30 December 2008 No. 307-FZ) establishes a right, but not a duty for auditors, to insure their professional liability (in contrast with the earlier Act 7 August 2001 No. 119-FZ).

The Arbitration court of Moscow rejected the claim by a decision of 30 September 2015. The decision was upheld by the courts of appeal and cassation. In resolving the dispute, the courts proceeded from the fact that in accordance with Art. 17 (6) of the Audit Activity Act (2008) a self-regulatory auditor's organization is entitled to establish additional requirements for its members. The requirement for insurance of professional liability does not contradict the law and does not violate the plaintiff's rights, as it is aimed at providing compensation for damage to clients of audit firms (see Russian Supreme Court judgement 23 May 2016 No. 305-ЭC16-4175).

In relation to certain types of activity, the law provides only the right (not the duty) of legal and natural persons to carry out insurance of professional risks: lawyers ${ }^{16}$, healthcare organizations and doctors ${ }^{17}$. In practice, only a few subjects use this opportunity. As objections to the introduction of obligatory liability insurance in these areas, the following circumstances are usually cited: a small number of claims from injured and insignificant amount of possible damage that a person is able to compensate on its own - instead of paying an annual insurance premium ${ }^{18}$.

Some of these arguments are no longer relevant. Currently, courts deal with a large number of claims against lawyers (for legal malpractice), as well as claims of patients or their relatives against healthcare organizations and doctors (for medical malpractice). According to S. K. Kusherbayev (M. D.), the number of patients' claims for compensation has increased over the past five years by 25 times, while even a single lawsuit can lead to bankruptcy and put an end to the further career of a doctor. This problem can be solved by creating special compensation funds or by establishing of professional liability insurance for healthcare organizations ${ }^{19}$. Survey, conducted among professionals

${ }^{16}$ In according to par. 1 (b) Art. 7 of the Advocate Activity Act attorneys are required to have professional liability insurance. However, this provision is suspended until to entry in force of the law, regulating the issues of compulsory insurance of professional liability of attorney.

${ }^{17}$ In according to par. 7 Art. 72 of the Public Health Act healthcare professionals and pharmacist have the guarantees provided by the labor legislation, including the right to insure the risk of the professional liability.

${ }^{18}$ See: Sharov G. K. Advocate Activity Act on insurance of attorney's liability. Attorney, 2004, no. 12 (In Russ.).

${ }^{19}$ See: Kusherbaev S. K. The professional liability insurance of healthcare professionals. Medical law, 2009, no. 3, pp. 41-43 (In 
with the high risk of getting harm to third parties, shows that the development of professional liability insurance is seriously hindered by the low level of financial literacy and by the lack of understanding of the goals of this insurance ${ }^{20}$. However, even if there is no legal duty, the professional liability insurance is wanted in those areas where the level of liability to third parties for damages is incomparably higher than the average cost of services rendered. In particular, professional liability insurance (voluntary) is quite popular among persons providing intermediary services in real estate - realtors and real estate agencies. In the absence of legal regulation of real estate activities, such type of insurance is the only guarantee for consumers, which allows them to get compensation for losses within a reasonable time.

LLC "Vizit-nedvizhimost" (Estate agency) sued JSC "AlfaStrahovanie" for insurance payment under the contract of realtor's professional liability insurance. In accordance with the contract, the insurance covers nonintentional errors and omissions of the realtor that caused damage to the client. During the insurance period OOO "Vizit-nedvizhimost" (agent) has concluded the contract with Ms. Sh. (client), under which the agent undertakes to search for client an apartment in Samara, to provide legal support, including the proper drafting of deal.

On the basis of the search, the plaintiff offered Ms. Sh. for purchase an apartment worth 4,200,000, drafted the sales contract. Ms. Sh. approved this option and made payment for the apartment. Further, this contract was canceled by a court decision, since it was signed by a person who is not the owner and does not have the authority to sell the apartment. In accordance with another court decision, LLC "Vizit-nedvizhimost" is obligated to compensate Ms. Sh. damages in the amount of the paid cost of the apartment 4,200,000. Plaintiff executed this court decision, after that applied for an insurance payment to JSC "AlfaStrahovanie". However, the insurer refused to pay.

The claim was satisfied by the decision of the Arbitration court of the Samara region on 28 December 2015. The court of appeal upheld this decision. The courts found the Estate agency's complaint justified, since the damage was caused due to unintentional professional error of realtor in the course of real estate activities improper verification of seller's authority, as well as title documents for the apartment (see the judgement of

Russ.). As an example, may refer to the case JSC MRC "Health for You" v. JSC SK "Alliance" about recovery of insurance payment under the contract of liability insurance of healthcare professionals. The damage, caused to patient by the poor quality of medical care (delayed diagnosis and complication of the existing disease) amounted more than 5 million. See: Ninth Arbitration Court of Appeal judgement of 22.04.2015 No. 09AП-13725/2015).

${ }^{20}$ See: Afanasyeva O. Y., Malukov A. V. The dentist's opinion about the professional liability insurance. Medical law, 2009, no. 2 (In Russ.).
Arbitration Court Volga's District of 13 July 2016, case No. A55-23689/2015).

Comparing the experience of Estonia and Russia, it should be noted that there are features in the legal and judicial systems of these States, which in some cases interfere with the development of professional liability insurance. For instance, in Estonia, bailiffs who enforce court decisions are not public servants and take responsibility for damage on their own, so they are obliged to insure the risk of this liability. In Russia, bailiffs, on the contrary, are the part of the governmental system. The burden of responsibility for their illegal acts (omission) is imposed on the State (Art. 1069 of the Civil Code). The number of such lawsuits to the State and the total volume of claims are impressive. However, in Russia there is no experience of liability insurance (with State as policyholder or insured) for damages caused by illegal acts of officials. Therefore, without a serious reform of enforcement proceedings and changing the status of the bailiff, the prospects for the development of professional liability insurance in this area are insignificant.

\section{An insured event with obligatory professional} liability insurance

The biggest problem with liability insurance is what and how to define an insured event, which is the basis for the insurer's performance obligation. In the Republic of Estonia, the law does not give a specific answer to this. Namely, $\S 510$ of the Law of Obligations Act (LOA) stipulates that in liability insurance, the insurer shall, in place of the policyholder, perform the obligation to indemnify for damage caused by the policyholder to a third party (injured party) as the result of an insured event which occurs during the period of validity of the insurance and to cover the costs of legal assistance. It is therefore questionable which event should be considered as an insured event in the case of liability insurance, whether: the policyholder's offense; the occurrence of damage; the policyholder's knowledge of the offense and/or damage caused; submission of a claim against the policyholder?

According to insurance theory and practices, it is possible to distinguish between different definitions of an insured event:

Occurrence trigger, according to which the insured event is the occurrence of damage to a third-party during policy period. The occurrence trigger approach allowed for claiming the damages also after the termination of the insurance contract during a certain period laid down in the insurance contract (so-called extended reporting period, which in practice is generally one to two years). Therefore, in the event of an occurrence trigger, it is important that the damage occurs during the insurance period. For example, a lawyer will provide legal services in 2019 and make a mistake in 2019 (for example, failing to submit evidence to the court in due time), while a negative judgement regarding the client will be made by the court in 2020. In this case, if the lawyer has liability 
insurance with an occurrence trigger, the damage will be indemnified under the 2020 insurance contract.

According to the claims made trigger, the insured event is the filing of a claim with the insurer. According to the claims made trigger, it is not important when the offense occurred, but the insured event is the filing of a claim arising from that offense, regardless of the time difference between the filing of the claim and the offense. What matters here is that the insurance contract between the insurer and the policyholder must be valid at the time the claim is made. According to the claims made trigger, no claim can be made after the insurance contract expires. Example of a claims made trigger: For example, a lawyer will provide legal services in 2016 and make a mistake in 2016 (for example, failing to submit evidence to the court in due time), while a negative judgement regarding the client will be made by the court in 2017. However, the injured party will only file the claim against the lawyer in 2018. In this case, if the lawyer has liability insurance with the claims made trigger, the damage will be indemnified under the 2018 insurance contract. Claims made trigger is predominantly used in, for example, US professional liability insurance. In accordance with the claims made trigger, the insurance cover however does not extend to damages that the policyholder was aware of before the start of the period of insurance, even although the claim had not yet been made. In the case of a claim made trigger, a retrospective period is usually agreed upon, during which if errors/mistakes were made, they will be compensated.

According to the act committed trigger, the insured event is the commission of the act, which led to the consequence, i.e., the offense (the consequence may come later than the act). The Act committed trigger must therefore have been an offense that occurred during the term of the insurance cover; damage and claim may occur later. Act committed trigger is used, for example, in professional liability insurance ${ }^{21}$, where it is possible to determine when an offense occurred. An example of

${ }^{21}$ Most Estonian insurers use the corresponding trigger for compulsory professional liability insurance terms and conditions. For example, ERGO Insurance SE provides in clause 4.1 of KT.0432.09 of the Attorney's Professional Insurance Terms and Conditions that the insured event is a violation of the insured person's professional activity during the insurance period, resulting in the insured person having a statutory liability for damages (available at: https://www.ergo.ee/files/Advokaadi_ kutsekindlustuse_tingimused_KT.0432.09.pdf). Terms and Conditions of Notarial Insurance of Notary Public of AB "Lietuvos Draudimas" Estonian Branch T005/2016 clause 2.1. provide that the insured event is a wrongful act during the insurance period (hereinafter referred to as an event) which is causally related to the profession of a notary and as a result of which the insured person has a statutory obligation to indemnify the damages (available at: https://pzu.ee/wp-content/uploads/2019/01/Notariametikindlustuse-tingimused.pdf). an act committed trigger example: lawyer provides legal service in 2016 and makes a mistake in 2016 (for example, failing to file evidence in due time) while a negative judgment for the client will be made by the court in 2017. However, the injured party will only file the claim against the lawyer in 2018. In this case, if the lawyer has liability insurance with the act committed trigger, the damage will be indemnified under the 2016 insurance contract. There is generally a specified notification period laid down in the insurance contract (so-called sunset period which in practice is three to ten years).

According to the manifestation trigger, the insured event is becoming aware of the consequences (damage). It is therefore important for the manifestation trigger to know during the insurance period that damage has occurred. Example of a manifestation trigger: A lawyer provides legal services in 2016 and makes a mistake in 2016 (for example, failing to file evidence in due time), while a negative judgement regarding the client will be made by the court in 2017. However, the injured party will only file the claim against the lawyer in 2018. In this case, if the lawyer has liability insurance with the manifestation trigger, the damage will be indemnified under the 2017 insurance contract.

Nonetheless, there is a practical problem when it comes to the triggers: for example, if one insurance contract is concluded with an act committed trigger and the next one is concluded with a claims made trigger, and the act occurred during the time in which the previous contract was in force, an overlapping (double) insurance cover comes into being. And also vice versa: if the previous insurance contract was concluded with a claims made trigger and the next one with an act committed trigger, then in case of a similar damage, there is no insurance cover. Therefore, understanding the triggers is of crucial matter for the policyholder - otherwise he/she can harm himself/herself financially (be left without insurance cover or pay double).

It has been found in Estonian legal literature ${ }^{22}$ that, although the law does not explicitly regulate this issue, according to the Law of Obligations, determination of an insured event should in the case of liability insurance, however, be based on the occurrence of an offense. This means that the insurer should indemnify the policyholder for any damage committed by the policyholder during the term of the insurance cover. Such damages should also be indemnified if the damage occurs or the injured party claims damages only after the termination of the insurance contract. It should also be borne in mind that in order for the insurer to fulfill its performance obligation, there must also be some damage occurred after the offense and a claim against the policyholder, in which it also matters whether the policyholder is liable at all. Janno Lahe considers that the standard clause, according to which the insurer's performance obligation arises only if both the offense, the

\footnotetext{
${ }^{22}$ Lahe J. Kindlustusõigus 137. Tallinn, 2007.
} 
damage and the claim have occurred during the term of the insurance contract, shall be considered unreasonably harmful to the policyholder. Such an approach would essentially mean that the policyholder would be forced to remain in the insurance relationship even after he or she had ceased his activity, perhaps even for the rest of his or her life, because the damage could emerge and the injured party would continue claim damages against him or her years after the offense.

Professional literature ${ }^{23}$ has also taken the view that a literal interpretation of $\S 510$ of the LOA may indeed suggest that the law considers an offense of the policyholder to be an insured event, as the wording of the provision is in favor of such an understanding: damage caused by the policyholder to a third party (injured party). However, there are differences of opinion that filing a claim as an insured event is precluded because it would damage the policyholder's interests and make the insurer liable for any damage caused by the policyholder before the conclusion of the insurance contract. The rationale is that treating one or another event as an insured event, e.g., an offense or submission of a claim as an insured event is not actually detrimental to the policyholder's interests, as the latter may be just as interested in the securing of the filing of the claim as in securing the moment of the damage. In this case, the actual economic consequences of the insured will only arise if a claim is made by a third party. Similarly, the fact that the act giving rise to damage has already been committed by the time of conclusion of the insurance contract does not automatically preclude a claim-based insurance contract. Namely, the information obligations of the policyholder preclude the occurrence of such an offense, which results in an insured event of which the policyholder is aware at the time of entering into the contract, and the insurer is not. An analysis of the edition of the Law of Obligations Act has found that in no case should submission of a claim be considered as an insured event. The reasons for this position are the possible time difference between the offense and the filing of the claim, thereby damaging the policyholder's interests and the fact that otherwise the insurer would also be liable for the damage caused by the policyholder before the conclusion of the insurance contract. The comments indicate that if a person wishes his or her liability to be insured, which may have arisen from the possible occurrence of past damage, he or she can apply for retroactive insurance cover in accordance with $\S 438$ of the $\mathrm{LOA}^{24}$.

In Estonia, there is a trigger provided in only one of the laws regarding the professional liability insurance. It is the auditor's activities act, of which the section 63 subsection 2 clause 2 provides that "the insurance

\footnotetext{
${ }^{23}$ Hiob T. Rights of policyholder and injured party in liability insurance: Master's thesis. Tartu, 2010.

${ }^{24}$ Varul P. et al. Law of Obligations Act II, 553. Annotated edition. Tallinn, 2007.
}

cover applies to damage which is caused by an event or act which took place during the period of insurance", that means that the act committed trigger is provided by the law. The authors consider that this type of a specific provision of a trigger in law is reasonable and necessary and should always be provided in the interests of policyholders and injured parties.

In Russian law, regulating certain types of obligatory professional liability insurance, an insurance event is defined as an occurrence of damage to a third party, caused by acts or omissions in contradiction with the requirements of law, federal standard of activity, etc. For instance, in accordance with Art. 18 of the Notary Act an insured event is an occurrence of damage to a third party caused by unlawful notary's act or unlawful refusal to perform a notarial act, as well as disclosure of information about a notarial act, confirmed by an effective court decision or recognized by the insurer. The insurance contract shall be concluded for a period of at least one year and provide coverage for damage caused during the period of the contract ${ }^{25}$.

Nevertheless, it should not be considered that the legislator, giving the above definition, aimed to specify a moment of occurrence of the insured event (trigger) under the contract of professional liability insurance. Just as in Estonian, in the Russian literature scholars discuss the same ways of determining the moment of occurrence of an insured event: occurrence trigger, claim made trigger and act committed trigger ${ }^{26}$. In turn, in the standard insurance terms and conditions (of leading Russian insurers) an insured event under the contract of professional liability insurance is usually associated with the moment, when the insured made a professional mistake (error, omission), while a damage and claim may occur later ${ }^{27}$.

${ }^{25}$ Similarly, through the fact of causing damage during the term of insurance contract, the insured event is determined under the contract of compulsory liability insurance of appraiser (see Art. 24.7 of the Evaluation Activity Act). In contrast, the insured event under the contract of compulsory liability insurance of the bankruptcy trustee is described as the occurrence of bankruptcy trustee's liability, confirmed by an effective court decision (par. 5 Art. 24.1 of the Bankruptcy Act).

${ }^{26}$ See: Sotnikov S. L. Insured risk and insured event on the contract of professional liability insurance, Law, 2008, no. 5, pp. 64-66 (In Russ.).

${ }^{27}$ For instance, the Standard Rules of appraiser's liability insurance of (JSC IC "Rosgosstrah", of 16 March 2005, no. 19) define the insured event as a fact, established by a judgment or recognized by the insurer, of causing damage by the acts or omission of the insured in violation of the requirements of federal rules and standards of evaluation. The act that led to the damage must take place within the term of insurance contract. The date of professional error or omission, in particular, can be considered the date of determining the market value of the object. Similarly, the insured event is defined in clauses 4.3.1, 4.4.1 of the Standard Rules 
According to the authors of the article, when establishing obligatory liability insurance, the legislator should stipulate, among other things, what is to be considered as an insured event - this is important for ensuring uninterrupted insurance coverage. If the policyholder changes the insurer for obligatory liability insurance (e.g., for a new insurance period) and the insurance provided by the latter insurer is triggered differently, in theory a situation may occur be that the protection of the injured is not guaranteed (there will be a period without insurance coverage). Moreover, even when concluding a liability insurance contract with the same insurer, there may be "gaps" in coverage due to the fact that the insurer makes changes to the standard insurance rules and differently determines the insured event.

LLC "Residence" (Agency) filed a claim to JSC "AlfaStrahovanie" for an insurance indemnity. The court found that the parties had concluded a contract of realtor's professional liability insurance from 15 March 2016. During the period of contract, a court decision was made (11 October 2016) on the recovery of damages in amount 159,400 from the Agency in favor of Khudyakova (customer). Considering this circumstance as an insured event, LLC "Residence" applied to JSC "AlfaStrahovanie" with a claim for compensation.

Since the professional error, due to which Khudyakova recovered damages from the LLC "Residence", was committed at 13 January 2015 (as established by the court decision of 11 October 2016), the court has concluded in this case, that the event occurred before the insurance contract had been concluded. The claim was dismissed.

In the appeal, the plaintiff referred to another insurance contract between LLC "Residence" and JSC "AlfaStrahovanie" of 2 April 2014, which was in effect at 13 January 2015. This argument of the plaintiff was also rejected, because by virtue of p. 4.3 contract of 2 April 2014 the insurance covers only claims brought

of notaries' civil liability insurance (JSC IC "Rosgosstrakh", of 24 December 2004, no. 119): damage caused by a notary as a result of illegal notarial act or refusal of act contrary to the law, provided that the corresponding act was committed within the term of insurance contract. Available at: https://www.rgs.ru/ (12.01.2020). The act committed trigger does not cause any problems for the courts when considering the relevant insurance disputes. For instance, see the judgement of Arbitration Court of Moscow District of 14.05.2018, case № A40-108756/2017 (LLC “Zhilfond-2” filed a claim to JSC "AlfaStrahovanie" for recovery of payment under the contract of realtors' professional liability insurance of 17 August 2015. The court found, that the lawsuit was in connection with the recovery of the insured person (LLC "Zhilfond-2") in favor F. (client) losses in the amount of 600,000 . The losses were caused due to the breach of agency contract of 16 February 2016 - improper verification of the seller's power. Since the professional error took place within the period of insurance contract, the court upheld the claims of LLC “Zhilfond-2”). during the contract period and for errors made by the policyholder during the contract period. Neither the event that occurred on 13 January 2015, nor the Khudyakova's claim dated 8 December 2015 do not fall within insurance coverage under any of the insurance contracts concluded with JSC "AlfaStrakhovanie" (see the Ninth Arbitration Court of Appeal judgement No. 19 February 2018 09AP67899/2017).

\section{The actio directa principle}

Modern European obligatory liability insurance is characterized by the application of the actio directa principle in obligatory liability insurance. The actio directa principle means the right of the injured party to bring a direct action against the insurer of the person causing the damage ${ }^{28}$. This principle has emerged to counterbalance the notion that a direct claim against the insurer of the party causing the damage is not permissible insofar as it would be incompatible with the principle of contractual relations. Modern continental European insurance theory considers that the liability aspect of the tortfeasor and the insurance aspect cannot be separated and treated as two different issues. This change in opinion is due to the fact that otherwise, the interests of the policyholder that caused the damage would prevail. At the same time, European insurance law has become more and more victim-centered, and so liability insurance must serve the interests of the injured party, not so much the party who caused the damage. One of the primary implementers of the Actio directa principle in insurance law is Sweden, with its Insurance Act of 1927, and Norway's Insurance Act of 1930, which first allowed in certain cases the injured party the direct right of claim against the insurer of the liability insurance of the party that caused the damage. At present, the principle of actio directa is considered natural in most continental European countries for obligatory liability insurance (especially motor third party liability insurance). This change in insurance theory reflects a shift in the perception of society where the concept of compensation of damages as a subjective and individualistic approach is becoming an objective and collective approach ${ }^{29}$.

${ }^{28}$ The Actio directa principle applies only to obligatory liability insurance. In German law, the following arguments justify the lack of direct action by the injured third party against the insurer in the case of voluntary liability insurance. German law denies, in the case of voluntary liability insurance, direct legal relations between the injured third party and the liability insurer. Instead, a distinction is made between the so-called cover relationship (Deckunsverhältnis) between the liability insurance policyholder and the insurer and the so-called remediation relationship (Haftpflichtverhältnis) between the liability insurance policy holder and the injured third party. As a result, an injured third party can generally only claim damages against the policyholder who caused the damage. See: Haavasalu K. Juridica, 2007, No. 2.

${ }^{29}$ Wahlgren P. Tort liability and insurance. Stockholm, 2001. 
In the Republic of Estonia, the principle of actio directa is expressed in $\S 521$ (1) of the Law of Obligations Act $^{30}$ (the obligatory provision governing obligatory liability insurance), which provides that an injured party may demand the indemnification of damage caused thereto by the policyholder from both the policyholder and the insurer. In the relation between the insurer and the policyholder, as a rule, the insurer is solely liable ${ }^{31}$.

In Russian law the right of the injured party to apply for compensation directly to the insurer is provided only in cases of obligatory third-party liability insurance ${ }^{32}$, that is, tort liability (par. 4 Art. 931 of the Civil Code). At the same time, the principle actio directa is not explicitly stated in relation to liability insurance for breach of contract (Art. 932 of the Civil Code) ${ }^{33}$. Thus, the victim's rights depend on how the relevant contract of professional liability insurance will be qualified - as a liability insurance for damage or liability insurance for breach of contract $^{34}$.

The law also does not precisely regulate the issue of how the policyholder (person, causing the damage) and the insurer compensate the damage to injured

\footnotetext{
${ }^{30}$ Available at: https://www.riigiteataja.ee/en/eli/507032019001/ consolide.
}

$31 \S 521$ (2) of the LOA provides that if a claim for the indemnification of damage is filed against both the policyholder and the insurer, they shall be liable as solidary obligors. In the relationship between the insurer and the policyholder, only the insurer shall be liable. If the insurer is released from its performance obligation, only the policyholder shall be liable for performance of the obligation in the relationship between the insurer and the policyholder.

${ }^{32}$ In a third-party insurance claim, there are three parties. The first party is the policyholder. The second party is the insurance company. The third party is victim. In third-party insurance claim is made ordinary by someone who is not the policyholder or the insurance company.

${ }^{33}$ However, even in this case, the insurance contract is considered to be concluded in favor of a third party - to which the policyholder to which the policyholder should be liable for breach of contract (par. 3 Art. 932 of the Civil Code). This qualification allows Russian legal scholars to argue about the effect of principle of actio directa also in the relations of contractual liability insurance. See: Bandurina N. V., Bibikov A. I., Vavilin E. V. et al. Article-byarticle commentary to the Civil Code of Russia, to second part: in 3 vol. Ed. by P. V. Krasheninnikov. Moscow, 2011 (In Russ.).

${ }^{34}$ As it rightly noted in literature, the professional activities of certain entities associated with the risk of causing damage to both its counterparty and third parties. Accordingly, it is proposed to consider professional liability insurance as a separate category. See: Romanova I. N. Theoretical and legal analysis of legislation and practice in the field of liability insurance of some business entities. Law and Economics, 2017, no. 11, p. 57 (In Russ.). The opposite approach, see: Nozhkina A. A. The professional liability insurance in the system of the existing types of insurance. Current issues of Russian Law, 2013, no. 10, pp. 1257-1258 (In Russ.). party. On the one hand, according to the Art. 1072 of the Civil Code, a person who has insured his liability as a voluntary or obligatory insurance in favor of the injured, is obliged to compensate only the difference between the insurance payment and the actual amount of damage (if the insurance payment is insufficient for full compensation). On the other hand, due to the general rule of par. 1 Art. 1064 of the Civil Code the injured party is entitled to demand full compensation from the person who caused the damage. In court practice, the prevailing approach is that the victim has the right to choose who to address the claim for damage ${ }^{35}$.

S. A. sued LLC "Erlang" North-West" for damage caused as a result of improper building repair (during hydraulic testing, the plaintiff's apartment was flooded). The claim was denied by judgement of the Petrograd district court of St. Petersburg of 27 March 2017. The court found that at the time of repair work the civil liability of defendant was insured in JSC SK "Alliance", while the amount of damage does not exceed the insurance sum. Based on these circumstances, the court concluded, that claim was brought against an improper defendant.

The appellate court set aside this decision and pointed out that by virtue of the Art. 1072 and par. 4 Art. 931 of the Civil Code, the injured party does have a direct right of claim against the insurer of liability. However, this does not preclude him, according to par. 1 Art. 1064 of the Civil Code, from suing person, caused the damage (appellate ruling of St. Petersburg city court No. 3323044/2017 of 24 October 2017) ${ }^{36}$.

\section{Practical problems in obligatory professional} liability insurance based on Estonian and Russian law and insurance practices

\subsection{Deliberate damage and obligatory professional} liability insurance

The general principle of insurance is that intentional damage is not subject to compensation. For example, $\S 452$ (1) of the Law of Obligations Act lays down the general principle that an insurer shall be released from the performance obligation if the policyholder, the insured person or the beneficiary intentionally caused the occurrence of the insured event. Any agreement which derogates from this requirement is void. An analogous exclusion is also in voluntary liability insurance, for which $\S 513$ of the LOA stipulates that an insurer shall be released from its performance obligation if the policyholder intentionally and unlawfully caused the occurrence of the event due to which the liability of the policyholder with respect to the injured party arises. The exclusion of intent to indemnify under insurance

${ }^{35}$ The judgments on recovery of damage from the policyholder (insured) and the insurer in solidarity are not known.

${ }^{36}$ See also: Supreme Court judgment of 17 May 2018 No. 305-ЭC17-20897, case No. A40-210876/2016. Access from SPS "Consultant Plus". 
law serves primarily the purpose of excluding insurance fraud. However, the question can be asked whether in obligatory professional liability insurance, where the interests of the injured party are primarily protected, is exclusion of intent absolute ${ }^{37}$ ? In such a case, is the objective of introducing obligatory liability insurance not deviated from $\S 525$ (1) of the LOA regulating liability insurance sets out the principle that if, upon the insurance of insured risk relating to a third party, the insurer is released from its performance obligation with respect to the policyholder, the insurer shall only be released from its performance obligation with respect to the third party if the circumstances which are the basis for such release arise from the third party or if the third party was or should have been aware of these circumstances ${ }^{38}$. This may lead to the assumption that this is a special rule for $\S 452$ (1) and 513 of the LOA and that any damage intentionally caused by the policyholder in obligatory liability insurance is subject to indemnification to the insured party, however, in internal relations, the insurer shall be relieved of its obligation to indemnify the damage and shall file a recourse against the policyholder. Such an interpretation supports the objectives of introducing obligatory liability insurance. This principle has also been confirmed by the Supreme Court of the Republic of Estonia in its judgment No. 3-2-1-150-15, holding that in the case of obligatory liability insurance the division of liability between the insurer and the policyholder is governed by the second and third sentences of $\S 521$ (2) of the $\mathrm{LOA}^{39}$. If the insurer is released from its performance obligation, only the policyholder shall be liable for performance of the obligation in the relationship between the insurer and the policyholder. According to the wording of the third sentence of $\S 521$ (2) of the LOA, the precondition for release from liability is the

${ }^{37}$ For example, under Estonian law, in the event of damage caused intentionally under motor vehicle liability insurance the injured party will be compensated for the intentional damage caused by the policyholder (basis: $\S 53$ (1) (1) of the Motor Insurance Act). Available at: https://www.riigiteataja.ee/en/eli/526032019008/ consolide Thus, in an internal relationship the insurer vs the policyholder release from the performance obligation occurs.

${ }^{38}$ Subsection 2 of this provision gives the insurer a right of recourse against the policyholder in respect of such damage ( $\$ 525$ (2) of the LOA): If, in the circumstances specified in subsection (1) of this section, the insurer is required to fulfill an obligation to a third party, the insurer may claim from the policyholder reimbursement of expenses incurred in the performance of the obligation to the third party).

${ }^{39}$ That subsection provides: If a claim for the compensation of damage is filed against both the policyholder and the insurer, they shall be liable as solidary obligors. In the relationship between the insurer and the policyholder, only the insurer shall be liable. If the insurer is released from its performance obligation, only the policyholder shall be liable for performance of the obligation in the relationship between the insurer and the policyholder. release of the insurer from the performance obligation. To understand the meaning of the release from the performance obligation, one has to keep in mind the regulation of $\S 521$ (5) of the LOA according to which the insurer shall not refuse to satisfy the claim of an injured party on the grounds that the insurer has been released from its liability to the policyholder in part or in full. Since in the case of obligatory liability insurance against the injured party, there can be no waiver of the insurer's obligation under $\S 521$ (5) of the LOA, this means that under the release of the performance obligation, the third sentence of $\S 521$ (2) of the LOA refers to the release of insurer of the performance obligation to the policyholder. The general principles provided by law for the insurer to be released from the obligation to perform in case of violation of the obligations of the policyholder are regulated by $\S 452$ of the LOA. The purpose of $\S 452$ (1) of the LOA is to exclude the insurer's obligation to pay the insurance indemnity in case of an intentionally caused insured event, but not to restrict the right of the parties to the insurance contract to agree on the right to refuse to pay compensation also for other forms of culpability. The purpose of this provision is to protect the insurer, as it renders null and void the agreements obliging the insurer to pay the indemnity in case the policyholder, the insured or the beneficiary intentionally causes the insured event to occur.

At the same time, there is another legal problem related to intent in obligatory professional liability insurance in Estonia: whether intentional damage has to be insured at all or is it an insured risk (if it is not an insured risk, then the next level, that is, the possible release of the insurer will not be achieved). For example, the second sentence of $\S 48$ (1) (2) of the Bar Association Act provides that liability for intentional breach of official duties need not be insured ${ }^{40}$. This raises the question of whether the legislator has wanted to give lawyers, etc., the choice of whether or not it wants to insure its liability for intentional breach or not? ${ }^{31}$ If so, what about the central principle of

${ }^{40}$ Notaries ( $§ 15$ (2) of the Notaries Act), bailiffs ( $\$ 10$ (2) of the Bailiffs Act), trustees in bankruptcy ( $\$ 64$ (2) of the Bankruptcy Act) and auditors ( $\$ 63(6)$ of the Auditors Activities Act) have exactly the same regulations.

${ }^{41}$ In practice, the insurers themselves do not have a common understanding of the above. For example, ADB Gjensidige Estonian Branch Terms and Conditions of Compulsory Professional Insurance of Attorneys VK108-2015 clause 5.2. provide that, if the insured event is the result of a deliberate breach of a lawyer's professional obligation, Gjensidige pays the injured party an insurance indemnity but reclaims the policyholder to pay the indemnity paid. The policyholder must pay the claim back to Gjensidige within two weeks of receipt of the claim filed at least in a format that can be reproduced in writing (available at: https://www. gjensidige.ee/-/media/kindlustustingimused/vastutus-ja-garantii/ vk108-2015.pdf). However, Salva Insurance Company Terms and Conditions of Compulsory Professional Insurance of Attorneys 
obligatory liability insurance, designed to protect injured parties? Is it really expected that the client always checks the insurance cover of the liability insurance of a lawyer, notary, etc.? In addition, the holders of these professions may also cause damage to third parties and in this case, there is no option to choose a service provider.

The expression "does not have to insure" used in Estonian law refers to the need that, in order to not insure for the liability for intentional research there must be an expression of the intent of the official. Conversely, if the legislator had been aware of a situation where intentional misconduct is not covered by obligatory liability insurance, the wording of the law should have been different (for example, "obligatory liability insurance does not cover liability for deliberate breach by the official, unless otherwise agreed in the contract"). Thus, it can be argued that the expression "does not have to insure" used in Estonian law has grammatically two possible interpretations: a) the parties can agree that the intentional damage is not at all covered by insurance risk $^{42}$; or b) it is a risk covered by an insurance contract, but the parties may agree that in the internal relations the insurer will be relieved of the performance obligation (after the indemnification it is possible to file a recourse claim against the policyholder who caused the damage intentionally). Unfortunately, there is no judicial practice in Estonia on this issue ${ }^{43}$.

According to the Russian law, the insurer shall be also released from liability, if the policyholder, the beneficiary or the insured person intentionally caused the occurrence of the insured event (par. 1 Art. 963 of the Civil Code). An exception to this rule is made for personal insurance

clause 6.2 provide the insured event is not a deliberate breach of an obligation in the course of professional activity, as a result of which the policyholder is obliged to indemnify (available at: https://www. salva.ee/sites/default/files/content-editors/tingimused/Vastutus/ advokaatide_kohustusliku_kutsekindlustuse_tingimused_akt15.11.pdf).

${ }^{42}$ In Germany, for example, this is permissible. Under $\S 51$ (3) (1) of the Bundesrechtsanwaltsordnung, a lawyer may exclude from compulsory liability insurance liability arising out of deliberate breach of an obligation (available at: https://www.gesetze-iminternet.de/brao/BJNR005650959.html).

${ }^{43}$ In the most well-known analogous case in Estonia, the so-called Autorollo bankruptcy proceeding in a claim for damages (Civil Case no. 2-12-50785 - it involved depriving the company client OÜ Autorollo of the assets by the lawyer in the course of his professional activity, and subsequently an action for damages against the lawyer by the client's bankruptcy trustee) the attorney was also convicted of a criminal offense (Criminal Case No. 1-15-2699), ie the attorney's intent was determined, the insurer voluntarily compensated the damage intentionally caused by the lawyer under the obligatory professional liability insurance contract, although the standard terms and conditions of the insurer in question could have allowed for the conclusion that the intentional damage was not at all covered as an insurance risk. contracts, as well as for insurance of civil liability for harm caused to life and health (par. 2 Art. 963).

In turn, some federal laws (regulating obligatory liability insurance) mention a number of examples where the insurance payment must be made even if the policyholder commits a deliberate violation ${ }^{44}$. As a rule, in such cases, the insurer has the right of recourse against the policyholder. In particular, according to par. 9 Art. 24.1 of the Bankruptcy Act the insurer is entitled to make a recourse claim against the bankruptcy trustee (policyholder) if the losses are caused as a result of:

the deliberate acts or omission of the bankruptcy trustee, expressed in violation of provisions of the Bankruptcy Act, the requirements of other federal laws or professional standards and rules;

the unlawful obtaining of any material benefits during the execution of trustee's duties in the bankruptcy case, including illegal use of information received from the execution of professional duties ${ }^{45}$.

The number of such recourse claims satisfied is low, since the professional liability insurance is considered by the courts as a protective mechanism not only for potential victims, but also for the insured himself. Intentional acts, usually associated with gross violations by the insured of professional standards and with the obtaining benefits from the property of third parties. In this the onus of proving intentional guilt lies with the insurer. Previously rendered judgment on the action against an insurer (under the contract of professional liability insurance), as a rule, are not considered to be prejudicial in establishing of intent in the acts of the insured person (bankruptcy trustee).

LLC SK "Inertek" filed a recourse claim against bankruptcy trustee Y. The suit was satisfied by the Arbitration court of St. Petersburg. The decision was upheld by the supreme courts. The courts concluded that the defendant's guilt in causing the losses, compensated by the insurance company, was established by the

${ }^{44}$ With regard to voluntary insurance of professional liability (lawyers, realtors, healthcare organizations), Russian insurers prefer excluding intentional errors and omissions from coverage. See, for example: JSC IC "Rosgosstrach" Standard Rules of professional liability insurance of consultants (lawyers, auditors), of 23 July 2007 No. 125. In accordance with clause 5.1.6 of Rules, an event is not considered an insured event if the damage to property is caused by deliberate acts of the policyholder (insured). Acts are considered as deliberate if the damage (as consequence) is expected with a high probability and is deliberately allowed by the person, responsible for damage (available at: https://www.rgs.ru).

${ }^{45}$ See also par. 1 (1) Art. 19 Federal law of 14 June 2012 No. 67-FZ "On compulsory liability insurance of the carrier for causing harm to life, health, property of passengers and about the compensation of such harm caused during the subway transportation of passengers"; par. 1 (a) Art. 14 Federal law of 25 April 2002 No. 40-FZ "On compulsory motor third-party liability insurance". 
judgement on the previously considered case (for recovery of losses, caused to the insolvent debtor, managed by Y.), as well as by the court act on the removal of Y. from the bankruptcy trustee's duties.

The Supreme Court overturned all decisions on this case and dismissed the claim of LLC IC "Inertek" to Y. The judges had expressed the view, that the insurer's claim is actually aimed (despite the insured event took place), to avoid the obligation to pay indemnity. This is true only when the insured event does not have legitimate signs of probability and accident, occurred due to the intent of the insured. However, it does not follow from the content of judgment on the claim for insurance compensation (case No. A56-5968/2013). Moreover, the insurer didn't object against the insolvent debtor's claim, referring to intentional act of bankruptcy trustee as a cause of losses. In turn, courts didn't discuss this issue.

This circumstance does not deprive the insurer of the right to prove, that insured event occurred due to the defendant's intent. The relevant evidence is not provided by the insurer when considering this case. The courts, having accepted the position of the insurance company on the sufficiency of the circumstances established by the courts in previously considered cases, wrongfully released the insurance company from the burden of proving the necessary conditions for recourse claim. Meanwhile, the satisfaction of a recourse claim in the absence of necessary conditions leads to the fact that the mandatory by law liability insurance of bankruptcy trustee loses its meaning (Supreme Court judgment of 22 May 2017 No. 307-ЭC16-18707) ${ }^{46}$.

Such court practice, "loyal" to bankruptcy trustee, is supported by legal scholars. According to prof. Y. B. Fogelson, special provisions of par. 9 Art. 24.1 of the Bankruptcy Act encompasses a much larger list of cases than the provisions of par. 1 Art. 963 of the Civil Code, so the insurer have got a recourse right much more often than necessary. Meanwhile, the refusal of bankruptcy trustee in insurance cover in case of unintentional damages (even if he violated the requirements of law or professional standards intentionally) defeats the purpose of this type of insurance ${ }^{47}$.

Authors consider that in obligatory professional liability insurance, the legislation should be based on the assumption that it is established in the interest of the injured party, and just as in the case of motor third party liability, and just like the injured party cannot "choose"

\footnotetext{
${ }^{46}$ In another case the court rejected the recourse claim of LLC IC "Inertek" to Rafalsky for losses, pointing out that the mere violation of law and professional standards does not indicate the bankruptcy trustee's intent, it may also be a kind of gross negligence. See: the judgment of Arbitration Court of Northwest District of 31 July 2019, case No. A56-125695/2018.

${ }^{47}$ See: Fogelson Yu. B. The intent in insurance practice. Minus by minus is plus: to the practice of application of par. 9 of Art. 24.1 Bankruptcy Act. Bulletin of economic justice of Russian Federation, 2018, no. 4, pp. 135-136 (In Russ.).
}

with who the collision of cars takes place (and thus in the view of the injured party, the intent is covered), the professional liability insurance should not allow the policyholder to exclude intent from the insurance risk it could only be a basis for release in the internal relation (in other words, the parties could agree that in case of an intent, the insurer has a right of recourse against the policyholder). It seems to the authors an illogical interpretation that the more serious (in terms of form of culpability) the policyholder's breach is, the more likely it is that the injured party will be deprived of the insurance indemnity.

4.2. What is the legal consequence of an obligatory professional liability insurance contract not being concluded or not being concluded in accordance with the law?

In Estonian legislation, a number of laws provide for the obligation to conclude a professional liability insurance contract. What happens, however, if the relevant official has not concluded an insurance contract? Estonian law and judicial practice do not provide a direct answer to this question. For example, $\S 48$ (4) of the Estonian Bar Association Act states that certificates concerning the professional liability insurance of advocates shall be preserved in the Bar Association, but does the law not expressis verbis state what happens if the relevant obligation to keep the insurance contract is breached? What happens, for example, if the Bar Association has not checked the insurer's compliance with the insurance obligation - in such a case, could the Bar Association as a controlling body be liable (under tort law) to the injured party? ${ }^{48}$

In German law, the Insurance Contract Act ${ }^{49}, \S 117$ (2), provides that a circumstance which results in the nonexistence or the termination of the insurance agreement shall only be effective in consideration of the third party one month after the insurer has notified the competent agency of this circumstance. This shall also apply if the insurance agreement ends on account of time lapsed. The time limit does not commence before the insurance agreement has ended. A circumstance as described in the first and second sentences may also be cited against the third party if before the point in time at which the damage emerged the competent agency had received confirmation of a new insurance taken out based on a relevant law.

\footnotetext{
${ }^{48}$ In Russian law the legal consequences of non-performance (improper performance) of duty to conclude a liability insurance contract are defined in Art. 937 of the Civil Code: injured party (or beneficiary) is entitled to demand from the debtor to carry appropriate insurance (par. 1); upon the occurrence of insured event the debtor is liable to the victim (beneficiary) on the same terms the indemnity should have been paid upon the proper insurance (par. 2). These rules don't seem to be a strong guarantee for injured. There is no any court practice on application of these provisions.

${ }^{49}$ Versicherungsvertragsgesetz (VVG). Available at: https:// germanlawarchive.iuscomp.org/?p=861\#120.
} 
The above provisions of this division shall not apply if no competent agency has been appointed to receive the notification in accordance with the first sentence.

The authors consider that the obligation to check the validity of obligatory professional liability insurance should be placed on a professional organization (e.g., the Bar Association, Chamber of Notaries, etc.), which in turn makes the existence of a valid insurance contract a prerequisite for the relevant professional to operate. For example, the Bar Association verifies the existence of a valid insurance contract and, in the absence thereof, the membership of a lawyer in a professional organization is terminated. At the same time, insurers should be obliged to immediately notify the professional organization of the early termination of their insurance contract (for example, if the insurer terminates the insurance contract because the policyholder does not pay the premium properly). This would achieve a situation where the professional liability insurance would be valid for the entire duration of the person practicing the specialty and at the same time the claims of the injured persons would be secured, in other words the main purpose of the obligatory liability insurance would be achieved.

\section{Conclusion}

As a result of the study, the authors found that obligatory professional liability insurance serves the purpose of ensuring compensation for the injured party while maintaining the solvency of the person who caused the damage. State intervention in the risk management of natural and legal persons through the introduction of obligatory classes of insurance stems from the desire to provide economic insurance, to protect the interests of victims and to protect the person causing the damage from possible bankruptcy. Without state intervention, many risk-takers would not insure themselves. Thus, for the sake of society as a whole, it is necessary for the state to introduce obligatory insurance to manage certain risks. The expansion of the scope of obligatory professional liability insurance is an indicator of the state's attention to the property interests of its citizens (the social function of the state), although it may depend on the features of the legal system of the state.

An important principle of obligatory liability insurance is the principle of Actio directa - without recognizing this principle, obligatory professional liability insurance would not serve its main purpose: protecting the interests of the injured party. The approach of the Estonian legislator, according to which an injured party may demand the indemnification of damage from both the policyholder and the insurer (solidary obligors), seems to be more appropriate: it eliminates legal uncertainty in the choice of proper defendant, provides the victim with more prompt compensation for damage.

In professional liability insurance, the policyholder is best protected by a Claims made or Act committed trigger. The authors believe that the legislation could consider using these triggers in establishing all types of obligatory professional liability insurance.

Intentional damage caused to the injured party by the policyholder must be compensated - contrary to the general principle of insurance that intent is a circumstance releasing the insurer from the performance obligation. According to the authors, intent can only be a circumstance releasing the insurer in internal relations (i.e., the basis for submitting recourse against the policyholder).

The authors consider that the obligation to check the validity of obligatory professional liability insurance should be placed on a professional organization (e.g., Bar Association, Chamber of Notaries, etc.), which in turn makes the existence of a valid insurance contract a prerequisite for the relevant professional to operate. In the event that the relevant professional organization fails to fulfill its obligation to check the insurance contract properly, the relevant professional organizations (subsidiarity with the policyholder) should be liable to the injured party.

\section{References}

Afanasyeva O. Y., Malukov A. V. The dentist's opinion about the professional liability insurance. Medical law, 2009, no. 2. (In Russ.)

Bandurina N. V., Bibikov A. I., Vavilin E. V. et al. Article-by-article commentary to the Civil Code of Russia, to second part: in 3 vol. Ed. by P. V. Krasheninnikov. Moscow, 2011. (In Russ.)

Basedow J., Birds J., Clarke M. Principles of European Insurance Contract Law (PEICL). $2^{\text {nd }}$ ed. Köln, 2016. Pp. 309 -310.

Faure M., Van den Bergh R. Compulsory Insurance for Professional Liability, 14 (53). The Geneva Papers on Risk and Insurance, 312 (1989).

Fogelson Yu. B. The intent in insurance practice. Minus by minus is plus: to the practice of application of par. 9 of Art. 24.1 Bankruptcy Act. Bulletin of economic justice of Russian Federation, 2018, no. 4, pp. 135-136. (In Russ.)

Haavasalu K. Juridica, 2007, No. 2.

Hiob T. Rights of policyholder and injured party in liability insurance: Master's thesis. Tartu, 2010.

Honoré T. The Morality of Tort Law: Questions and Answers. Philosophical Foundations of Tort Law. Ed. by D. G. Owen. Oxford, 1995.

Kusherbaev S. K. The professional liability insurance of healthcare professionals. Medical law, 2009, no. 3, pp. 41—43. (In Russ.)

Lahe J. Kindlustusõigus 137. Tallinn, 2007.

Langheid T., Römer W. Versicherungsvertragsgesetz. 2 Aufl., Verlag C. H. Beck, München, 2003. S. 955, Rz 5. 
Nozhkina A. A. The professional liability insurance in the system of the existing types of insurance. Current issues of Russian Law, 2013, no. 10, pp. 1257-1258. (In Russ.)

Romanova I. N. Theoretical and legal analysis of legislation and practice in the field of liability insurance of some business entities. Law and Economics, 2017, no. 11, p. 57. (In Russ.)

Schlechtriem P. Law of Obligations. General part 18. Ver. 2. Tallinn, 1999.

Sharov G. K. Advocate Activity Act on insurance of attorney's liability. Attorney, 2004, no. 12. (In Russ.)

Sitdikova L. B., Shilovskaya A. L., Volkova M. A., Lenkovskaya R. R., Stepanova N. A. Legal Regulation of the Professional Liability Insurance of a Consultant in Russia and Abroad, Journal of Advanced Research in Law and Economics, 2016, vol. VII, iss. 2 (16), p. 364.

Sotnikov S. L. Insured risk and insured event on the contract of professional liability insurance, Law, 2008, no. 5, pp. 64-66. (In Russ.)

Varul P. et al. Law of Obligations Act II, 553. Annotated edition. Tallinn, 2007.

Wahlgren P. Tort liability and insurance. Stockholm, 2001.

Whelan C. J., McBarnet D. The "Crisis" in Professional Liability Insurance, 14 (53). The Geneva Papers on Risk and Insurance, 302 (1989).

\section{Теоретические и практические проблемы обязательного страхования профессиональной ответственности: сравнительный анализ законодательства России и Эстонии}

КРАТЕНКО Максим Владимирович, доцент кафедры гражданского права Сибирского федерального университета, федеральный судья в отставке, кандидат юридических наук

Россия, 660041, г. Красноярск, Свободный просп., 79

E-mail: maxkrat@yandex.ru

ЛУЙк Олави-Юри, присяжный адвокат адвокатской конторы “LEXTAL”, преподаватель страхового права в Тартуском университете, доктор юридических наук

Эстония, г. Таллин

E-mail: olavi@lextal.ee

DOI: $10.12737 / \mathrm{jflcl} .2020 .043$

Общим трендом сегодня является стремительное расширение сфер деятельности, в которых государствами вводится обязательное страхование профессиональной ответственности. Однако применительно к частному праву, основанному на принципе свободы договора, возникает вопрос: не нарушается ли действие указанного принципа? Авторы статьи исследуют основы страхования ответственности и наиболее дискуссионные проблемы данного института в контексте обязательного страхования профессиональной ответственности. Исследование основано на сравнительном анализе законодательства двух соседних государств: России и Эстонии (с учетом значительного влияния законодательства Евросоюза на законодательство и правовую культуру Эстонии). Отмечается, что расширение сферы обязательного страхования ответственности значительно снижает количество исков о возмещении вреда, поскольку многие требования о возмещении такового регулируются страховщиками в добровольном порядке (при наличии действующего страхового полиса). По мнению авторов, страхование ответственности преследует две основные цели: обеспечение своевременной компенсации вреда потерпевшему и предотвращение несостоятельности причинителя вреда. Данные цели оправдывают введение обязательного страхования ответственности в сфере оказания юридических услуг, медицинской помощи, осуществления оценочной деятельности и проч. Несмотря на различия в законодательстве об отдельных видах профессиональной деятельности, в юридической доктрине и судебной практике России и Эстонии обсуждаются сходные правовые проблемы: определение момента наступления страхового случая; возможность распространения страховой защиты на случаи умышленных действий; наличие у потерпевшего права выбора субъекта возмещения (в лице страховщика или причинителя вреда). Сравнительно-правовой метод исследования позволяет авторам в ряде случаев предложить оптимальные решения для указанных выше проблем.

Ключевые слова: actio directa, обязательное страхование, страхование профессиональной ответственности, профессиональные ошибки и упущения, страховой случай, act committed trigger, occurrence trigger, умышленное причинение вреда.

Для цитирования: Кратенко М. В., Луйк О.-Ю. Теоретические и практические проблемы обязательного страхования профессиональной ответственности: сравнительный анализ законодательства России и Эстонии // Журнал зарубежного законодательства и сравнительного правоведения. 2020. № 5. С. 81—94. DOI: 10.12737/jflcl.2020.043 (на англ. яз.) 